\title{
PEMBELAJARAN KITAB KUNING DI PONDOK PESANTREN KHUSUS AL-HALIMY SESELA
}

\author{
Ahmad Helwani Syafi'i \\ Program Studi Pendidikan Bahasa Arab, Universitas Muhammadiyah Mataram, Indonesia \\ ahelwani1407@gmail.com
}

\section{INFO ARTIKEL \\ Riwayat Artikel: \\ Diterima: 27 -06 -2020 \\ Disetujui: 30-10 -2020 \\ Kata Kunci: \\ Pembelajaran kitab kuning, \\ Pondok pesantren, \\ Pesantrem al-halimy sesela}

\section{Keywords:}

Yellow book learnin,

Boarding school,

Pesantrem al-Halimy Sesela

\section{ABSTRAK}

Abstrak: Metode merupakan suatu hal yang urgen dalam proses pembelajaran karena dengan penerapan metode yang sesuai dengan materi, diyakini tujuan pembelajaran dapat dicapai, termasuk pembelajaran kitab kuning yang tidak memiliki tanda baca atau disebut kitab gundul di Pondok Khusus Al-Halimy Sesela. Sejumlah metode yang diterapkan pada pembelajaran kitab kuning yaitu metode Bandongan atau Wetonan, Sorogan, Halaqoh, Diskusi, Tanya Jawab, dan metode Ceramah. Untuk mengetahui dan menganalisis penerapan dalam pembelajaran kitab kuning di Pondok Pesantren Khusus Al-Halimy Sesela. Untuk mengetahui dan menganalisis tingkat kesulitan-kesulitan yang dihadapi guru dalam penerapan metode pembelajaran kitab kuning di Pondok tersebut.

\begin{abstract}
Method is an urgent thing in the learning process because with the application of methods that are in accordance with the material, it is believed that the purpose of learning can be achieved, including learning the yellow book that does not have punctuation or called the bald book in Pondok Khusus Al-Halimy Sesela. A number of methods applied to the study of the yellow book are bandongan or Wetonan, Sorogan, Halaqoh, Discussion, Q\&amp;A, and Lecture methods. To find out and analyze the application in the study of the yellow book in The Special Boarding School Al-Halimy Sesela. To find out and analyze the level of difficulties faced by teachers in the application of yellow book learning methods in the cottage.
\end{abstract}

\section{A. LATAR BELAKANG}

Kitab kuning merupakan kitab yang memiliki tingkat kesulitan tersendiri dalam mempelajarinya, karena apabila berbeda harokat atau barisnya maka akan berbeda pula maknanya, jadi betulbetul dibutuhkan keahlian khusus dalam membaca dan memahami isi kitab kuning tersebut. Dengan demikian peran guru dalam menerapkan jenis metode yang tepat sangatlah dibutuhkan agar dapat mendekatkan atau mempermudah santri dalam menerima dan memahami pelajaran kitab kuning.

Kitab kuning selalu identik dengan Pondok Pesantren. Pondok pesantren adalah salah satu lembaga yang menyelenggarakan pendidikan baik formal maupun non formal, yang memiliki peran strategis dalam membina, membentuk dan mencetak generasi bangsa yang mampu bersaing di era modern seperti sekarang ini.

Pondok pesantren identik dengan kitab-kitab klasik atau yang disebut juga dengan kitab kuning. Sistem pembelajaran di pondok pesantren masih menggunakan sistim halaqoh. Halaqoh dari segi kebahasaan berarti "lingkarangan murid atau lingkaran belajar santri yaitu beberapa orang santri dengan jumlah tertentu membentuk halaqoh yang dipimpin langsung oleh seorang kiai atau ustaz atau juga santri senior untuk membahas atau mengkaji suatu persoalan yang telah ditentukan sebelumnya". 1 Jadi, santri duduk bersila mengelilingi ustadz yang mengajar sambil mendengarkan pengajian yang disampaikan oleh ustadz tersebut.

Kitab kuning sering disebut dengan istilah "kitab klasik (Al kutub Al-qadimah), kitab-kitab tersebut merujuk pada karya-karya tradisional ulama klasik dengan gaya bahasa Arab yang berbeda dengan buku modern". ${ }^{2}$ Ada juga yang mengartikan bahwa "dinamakan kitab kuning karena ditulis di atas kertas yang berwarna kuning". ${ }^{3}$ Akan tetapi Azyumardi Azra menjelaskan bahwa kitab kuning adalah "kitab-kitab keagamaan berbahasa Arab, Melayu, Jawa atau bahasa-bahasa lokal lain di Indonesia dengan menggunakan

Samsul Nizar,. Sejarah Sosial \& Dinamika Intelektual Pendidikan Islam di Nusantara (Jakarta, Kencana Prenada Media group. 2013), 163.

Endang Turmudi, Perseligkuhan Kyai dan Kekuasaan, (Yogyakarta: Lkis, 2004), 36

Ahmad Barizi, Pendidikan Intregratif: Akar Tradisi \& Intregasi Keilmuan Pendidikan Islam, (Malang: UIN Maliki Press, 20011), 62. 
aksara Arab, yang selain ditulis oleh ulama di Timur Tengah, juga ditulis oleh ulama Indonesia sendiri". ${ }^{4}$

\section{B. METODE PENELITIAN}

\section{Pembelajaran Kitab Kuning}

a. Pengertian Kitab Kuning

Kitab kuning sering disebut dengan istilah "kitab klasik (Al kutub Al-qadimah), kitab-kitab tersebut merujuk pada karya-karya tradisional ulama klasik dengan gaya bahasa Arab yang berbeda dengan buku modern". ${ }^{5}$ Ada juga yang mengartikan bahwa "dinamakan kitab kuning karena ditulis diatas kertas yang berwarna kuning, Jadi, kalau sebuah kitab ditulis dengan kertas putih, maka akan disebut kitab putih, bukan kitab kuning". 6

adalah:

$$
\text { Kitab kuning menurut Azyumardi Azra }
$$

Kitab-kitab keagamaan berbahasa Arab, Melayu, Jawa atau bahasa-bahasa lokal lain di Indonesia dengan menggunakan aksara Arab, yang selain ditulis oleh ulama di Timur Tengah, juga ditulis oleh ulama Indonesia sendiri. Pengertian ini, demikian menurut Azra, merupakan perluasan dari terminologi kitab kuning yang berkembang selama ini, yaitu kitabkitab keagamaan berbahasa Arab, menggunakan aksara Arab, yang dihasilkan oleh para ulama dan pemikir Muslim lainnya di masa lampau khususnya yang berasal dari Timur Tengah. ${ }^{7}$

Masdar F. Mas'udi dalam makalahnya, "Pandangan Hidup Ulama' Indonesia dalam Literatur Kitab Kuning", pada seminar Nasional tentang Pandangan Hidup Ulama' Indonesia mengatakan bahwa selama ini berkembang tiga terminologi mengenai kitab kuning.

Pertama, kitab kuning adalah kitab yang di tulis oleh ulama klasik islam yang secara berkelanjutan dijadikan referensi yang dipedomani oleh para ulama Indonesia, seperti Tafsir Ibn Katsir, Tafsir al-Khazin, Shahih Bukhari, Shahih Muslim, dan sebagainya. Kedua, kitab kuning adalah kitab yang ditulis oleh ulama Indonesia sebagai karya tulis yang independen, seperti Imam Nawawi dengan kitabnya Mirah Labid dan Tafsir al-Munir. Ketiga, kitab kuning adalah kitab yang ditulis oleh ulama Indonesia sebagai komentar atau terjemahan atas kitab karya ulama asing, kitabkitab Kyai Ihsan Jampes, yaitu Siraj al-Thalibin dan Manahij al-Imdad, yang masing-masing merupakan

${ }^{4}$ Azyumardi Azra, Pendidikan Islam: Tradisi dan Modernisasi Menuju Milenium Baru, (Jakarta: PT Logos Wacana Imu, 1999), 111.

${ }^{5}$ Endang Turmudi, Perseligkuhan Kyai dan ... Ibid, 36.

${ }^{6}$ Ahmad Barizi, Pendidikan Intregratif: Akar ... Ibid, 62. ${ }^{7}$ Azyumardi Azra, Pendidikan Islam: Tradisi ... Ibid, 111. komentar atas Minhaj al-'Abidin dan Irsyad al-'Ibad karya Al Ghazali. ${ }^{8}$

b. Ciri-ciri kitab kuning

Kitab-kitab klasik atau yang disebut dengan kitab kuning mempunyai ciri-ciri sebagai berikut:

a) Kitab-kitabnya berbahasa Arab;

b) Umumnya tidak memakai syakal, bahkan tanpa titik dan koma;

c) Berisi keilmuan yang cukup berbobot;

d) Metode penulisannya dianggap kuno dan relevansinya dengan ilmu kontemporer kerap kali tampak menipis;

e) Lazimnya dikaji dan dipelajari di pondok pesantren;

f) Banyak diantara kertasnya berwarna kuning. ${ }^{9}$

Bruinessen menambahkan "format kitab klasik yang paling umum dipakai di pesantren sedikit lebih kecil dari kertas kuarto $(26 \mathrm{~cm})$ dan tidak dijilid. Lembaran-lembaran (koras-koras) tak terjilid dibungkus kulit sampul, sehingga para santri dapat membawa hanya satu halaman yang kebetulan sedang dipelajari saja".10

Berbeda dengan Mujamil dalam Sahal Mahfuzh menjelaskan ada beberapa ciri kitab kuning yang di mesti ada dalam kitab kuning, yaitu Pertama, penyusunannya dari yang lebih besar terinci ke yang lebih kecil seperti kitabun, babun, fashlun, farun, dan seterusnya. Kedua, tidak menggunakan tanda baca yang lazim, tidak memakai titik, koma, tanda seru, tanda tanya, dan lain sebagainya. Ketiga, selalu digunakan istilah (idiom) dan rumus-rumus tertentu seperti untuk menyatakan pendapat yang kuat dengan memakai istilah Al-madzhab, Al-ashlah, as-shalih, Al-arjah, Alrajih, dan seterusnya, untuk menyatakan kesepakatan antar ulama beberapa madzhab digunakan istilah ijmaan, sedang untuk menyatakan kesepakatan antar ulama dalam satu madzhab digunakan istilah ittifaaqan".11

Dengan demikian, dalam kitab kuning mesti di lakukan atau dipetakan beberapa cirri khas yang melekat pada kitab kuning dan menjadi keunikan yang berbeda dari buku umum lainnya.

c. Jenis-jenis kitab kuning

Dalam beberapa literature Kitab kuning diklasifikasikan ke dalam empat kategori: “a) Dilihat dari kandungan maknanya, b) Dilihat dari kadar penyajiannya, c) Dilihat dari kreatifitas

\footnotetext{
${ }^{8}$ Ahmad Barizi, Pendidikan Intregratif: Akar ...Ibid, 61

${ }^{9}$ Muhaimin, Pemikiran Pendidikan Islam, (Bandung: Trigenda Karya, 1993), 300.

10 Martin Van Bruinessen, Kitab Kuning: Pesantren dan Tarekat, (Bandung: Mizan, 1995), 18.

${ }^{11}$ Sahal Mahfudh, Nuansa Fiqih Sosial, (Yogyakarta: LKiS, 1994), 264.
} 
penulisannya, d) Dilihat dari penampilan uraiannya".12

1) Dilihat dari kandungan maknanya

Adapun kitab kuning dilihat dari kandungan maknanya yakni kitab kuning dapat dikelompokkan menjadi dua macam, yaitu:

a) Kitab yang berbentuk penawaran atau penyajian ilmu secara polos (naratif) seperti sejarah, hadits, dan tafsir, dan

b) Kitab yang menyajikan materi yang berbentuk kaidah-kaidah keilmuan, seperti nahwu, ushul fiqih, dan mushthalah al-hadits (istilah-istilah yang berkenaan dengan hadits). ${ }^{13}$

2) Dilihat dari kadar penyajiannya

Adapun kitab kuning jika dilihat dari kadar penyajiannya dapat di bagi menjadi tiga macam, yaitu:

a) Mukhtasar yaitu kitab yang tersusun secara ringkas dan menyajikan pokok-pokok masalah, baik yang muncul dalam bentuk nadzam atau syi'r (puisi) maupun dalam bentuk nasr (prosa).

b) Syarah yaitu kitab yang memberikan uraian panjang lebar, menyajikan argumentasi ilmiah secara komparatif dan banyak mengutip ulasan para ulama dengan argumentasi masingmasing, dan

c) Kitab kuning yang penyajian materinya tidak terlalu ringkas dan juga tidak terlalu panjang (mutawasithoh). ${ }^{14}$

3) Dilihat dari kreatifitas penulisannya

Adapun kitab kuning jika dilihat dari kreatifitas penulisannya dapat dikelompokkan menjadi tujuh macam, yaitu:

a) Kitab yang menampilkan gagasan baru, seperti Kitab ar Risalah (kitab ushul fiqih) karya Imam Syafi'i, Al-'Arud wa Al-Qawafi (kaidah-kaidah penyusunan syair) karya Imam Khalil bin Ahmad Farahidi, atau teori-teori ilmu kalam yang dimunculkan oleh Washil bin Atha', Abu Hasan Al Asy'ari, dan lain-lain;

b) Kitab yang muncul sebagai penyempurnaan terhadap karya yang telah ada, seperti kitab Nahwu (tata bahasa Arab) karya As Sibawaih yang menyempurnakan karya Abul Aswad Ad Duwali;

c) Kitab yang berisi (syarah) terhadap kitab yang telah ada, seperti kitab Hadits karya Ibnu Hajar Al Asqolani yang memberikan komentar terhadap kitab Shahih Bukhari;

d) Kitab yang meringkas karya yang panjang lebar, seperti Alfiyah Ibnu Malik (buku tentang nahwu yang di susun dalam bentuk sya'ir sebanyak 1.000 bait) karya Ibnu Aqil dan $L u b b$ al-Usul (buku tentang ushul fiqih) karya Zakariya Al Anshori sebagai ringkasan dari Jam'al Jawami' (buku tentang ushul fiqih) karya As Subki;

e) Kitab yang berupa kutipan dari berbagai kitab lain, seperti Ulumul Qur'an (buku tentang ilmuilmu Al Qur'an) karya $\quad \mathrm{Al}_{=}$Aufi;

f) Kitab yang memperbarui sistematika kitabkitab yang telah ada, seperti kitab Ihya' Ulum Ad Din karya Imam Al Ghazali;

g) Kitab yang berisi kritik, seperti kitab Mi'yar Al 'Ilm (sebuah buku yang meluruskan kaidahkaidah logika) karya Al Ghazali. ${ }^{15}$

4) Dilihat dari penampilan uraiannya

Kitab memiliki lima dasar, yaitu:

a) Mengulas pembagian sesuatu yang umum menjadi khusus, sesuatu yang ringkas menjadi terperinci, dan seterusnya;

b) Menyajikan redaksi yang teratur dengan menampilkan beberapa pernyataaan dan kemudian menyusun kesimpulan;

c) Membuat ulasan tertentu ketika mengulangi uraian yang dianggap perlu sehingga penampilan materinya tidak semrawut dan pola pikirnya dapat lurus;

d) Memberikan batasan-batasan yang jelas ketika penulisnya menurunkan sebuah definisi; dan

e) Menampilkan beberapa ulasan dan argumentasi yang dianggap perlu. ${ }^{16}$

Sedangkan dari cabang keilmuannya, Nurcholish Madjid mengemukakan kitab ini mencakup ilmu-ilmu yang sering dan mesti serta banyak di pelajari di pondok pesantren seperti: fiqih, tauhid, tasawuf, dan nahwu sharaf. Atau dapat juga dikatakan konsentrasi keilmuan yang berkembang di pesantren pada umumnya mencakup tidak kurang dari 12 macam disiplin keilmuan: Nahwu, Sharf, Balaghah, Tauhid, Fiqh, Ushul Fiqh, Qawaid Fiqhiyah, Tafsir, Hadits, Musthalah Al-Haditsah, Tasawuf, dan Mantiq. ${ }^{17}$

d. Metode Pembelajaran

1) Pengertian Metode Pembelajaran

Dalam proses pembelajaran sering didengar yang namanya metode. Metode merupakan salah satu komponen pendidikan yang harus ada dalam proses pembelajaran, karena tanpa metode maka pembelajaran tidak bisa berjalan dengan baik dan tujuan pembelajaran tidak akan bisa tercapai.

\footnotetext{
${ }^{12}$ Said Aqil Siradj, Pesantren Masa Depan ...Ibid, 335.
${ }^{13}$ Ibid. 335

${ }^{14}$ Ibid. 335
} 
Pupuh Fathurrohman dan M. Sobry Sutikno menjelaskan bahwa "secara harfiah metode berarti cara. Dalam pemakaian yang umum, metode diartikan sebagai suatu cara atau prosedur yang dipakai untuk mencapai tujuan tertentu."18

Menurut Hamdani metode pembelajaran adalah:

Cara yang digunakan guru untuk menyampaikan pelajaran kepada siswa. Karena penyampaian berlangsung dalam interaksi edukatif, metode pembelajaran dapat diartikan sebagai cara yang dipergunakan oleh guru dalam mengadakan hubungan dengan siswa pada saat berlangsungnya pengajaran. Dengan demikian, metode pembelajaran merupakan alat untuk menciptakan proses belajar mengajar". ${ }^{19}$

2) Macam-macam Metode Pembelajaran

Dalam dunia pendidikan ada banyak macam metode yang digunakan untuk mentransfer ilmu pengetahuan agar memudahkan siswa dalam memahami pelajaran dan mempercepat siswa dalam mencapai tujuan pelajaran tersebut. Di antaranya adalah:

a) Metode ceramah

Menurut Syaiful Bahri Djmarah dan Aswan Zain metode ceramah adalah "metode yang boleh dikatakan metode tradisional, karena sejak dulu metode ini telah dipergunakan sebagai alat komunikasi lisan antara guru dengan anak didik dalam proses belajar mengajar". 20

Sementara itu Menurut Armai Arif metode ceramah adalah "cara menyampaikan sebuah materi pelajaran dengan cara penuturan lisan kepada peserta didik atau khalayak ramai". ${ }^{21}$

Dengan demikian dapat dipahami bahwa metode ceramah adalah cara penyajian pelajaran yang dilakukan guru dengan penuturan atau penjelasan secara lisan kepada siswa.

\section{b) Metode Tanya Jawab}

Metode tanya jawab adalah "cara penyajian pelajaran dalam bentuk pertanyaan yang harus dijawab, terutama dari guru kepada siswa, tetapi dapat pula dari siswa kepada guru".22 Menurut Abuddin Nata metode tanya jawab adalah "cara penyajian pelajaran dalam bentuk pertanyaan,

${ }^{18}$ Pupuh Fathurrahman dan M. Sobry Sutikno, Strategi Belajar Mengajar Melalui Penanaman Konsep Umum \& Konsep Islami. (PT Refika Aditama, 2010), 55.

${ }^{19}$ Hamdani. Strategi Belajar Mengajar (Bandung. Pustaka Setia. 2011), 80.

${ }^{20}$ Syaiful Bahri Djmarah dan Aswan Zain, Strategi Belajar Mengajar, (Jakarta: Rineka Cipta, 2014), 97.

${ }^{21}$ Armai Arif, Pengantar dan Metodologi Pendidikan Islam, (Jakarta: Ciputat Pers, 2002), cet. Ke-1, 135-136.

${ }^{22}$ Syaiful Bahri Djmarah dan Aswan Zain, Strategi Belajar Mengajar... Ibid, 94. yang dikemukakan oleh guru yang harus dijawab oleh peserta didik".23

Sedangkan menurut Darwyan Syah metode tanya jawab adalah "cara penyajian pengajaran oleh guru dengan memberikan pertanyaan dan meminta jawaban kepada peserta didik." ${ }^{24}$.

Sementara itu Ramayulis berpendapat bahwa metode tanya jawab adalah "suatu cara mengajar di mana guru mengajukan beberapa pertanyaan kepada peserta didik tentang bahan pelajaran yang telah diajarkan atau bahan bacaan yang telah mereka baca sambil memperhatikan proses berfikir diantara peserta didik". 25

Dengan demikian dapat dipahami bahwa metode tanya jawab adalah cara penyampaian pelajaran dengan cara guru mengajukan pertanyaan yang harus dijawab oleh siswa atau sebaliknya, dengan cara seperti ini akan dapat merangsang peserta didik untuk dapat mengemukakan pendapat dan pikiran masingmasing sesuai dengan tingkat pemahaman mereka.

c) Metode Diskusi

Diskusi dari aspek bahasa adalah tukar pikiran antara dua orang atau lebih untuk menyelesaikan suatu persoalan.

Kata diskusi berasal dari bahasa latin yaitu "discussus" yang berarti "tu examine", "investigate" (memeriksa, menyelidiki). Secara umum diskusi adalah suatu proses yang melibatkan dua orang atau lebih individu yang berintegrasi secara verbal dan saling berhadapan muka mengenai tujuan atau mempertahankan pendapat atau pemecahan masalah. ${ }^{26}$

Menurut Syaiful Bahri Djmarah dan Aswan Zain metode diskusi adalah "cara penyajian pelajaran, di mana siswa-siswa dihadapkan kepada suatu masalah yang bisa berupa pertanyaan atau yang bersifat problematis untuk dibahas dan dipecahkan bersama". ${ }^{27}$

Dengan kata lain, metode diskusi adalah suatu cara mendidik atau metode yang berupaya untuk menjawab atau memecahkan masalah yang dihadapi bersama-sama baik antara siswa dengan siswa atau antara siswa dengan guru yang masingmasing mengajukan argumentasinya atau memperkuat pendapatnya.

23 Abuddin Nata, Perspektif Islam Tentang Strategi Pembelajaran, (Jakarta: kencana Prenada Media Groum, 2009), cet. 1, 182-183.

${ }^{24}$ Darwyan Syah, Perencanaan Sistem Pengajaran Pendidikan Agama Islam, (Jakarta: Faza Media, 2006), cet. 1, 137.

${ }^{25}$ Ramayulis, Metodologi Pengajaran Agama Islam, (Jakarta: Kalam Mulia, 1990), 239.

${ }^{26}$ Samsul Nizar dan Zainal Efendi Hasibuan, Hadits Tarbawi: Membangun Kerangka Pendidikan Ideal Perspektif Rasulullah, (Jakarta: Kalam Mulia, 2011), cet. 1, 60.

${ }^{27}$ Syaiful Bahri Djmarah dan Aswan Zain, Strategi Belajar Mengajar...Ibid. 87. 
e. Metode pembelajaran kitab kuning

Diantara sikian banyak metode pembelajaran secara umum namun yang identik dengan pembelajaran kitab kuning ada beberapa metode saja yang sering digunakan dalam penerapan pembelajaran kitab kuning di pondok pesantren.

Menurut Zamakhsyari Dhofier dan Nurclolish Madjid dalam Said Aqil Siradj, "metode pembelajaran kitab kuning meliputi, metode sorogan dan bandongan, sedangkan Husein Muhammad menambahkan bahwa, selain metode wetonan atau bandongan, dan metode sorogan, diterapkan juga metode diskusi (munadzarah), metode evaluasi, dan metode hafalan". ${ }^{28}$

Adapun pengetian metode-metode tersebut adalah sebagai berikut:

\section{1) Metode Wetonan atau Bandongan}

Adapun Metode Wetonan atau Bandongan yaitu "cara penyampaian kitab di mana seorang guru, kiai, atau ustadz membacakan dan menjelaskan isi kitab, sementara santri, murid, atau siswa mendengarkan, memberikan makna, dan menerima". 29 Senada dengan yang diungkapkan oleh Endang Turmudi bahwa, "dalam metode ini kiai hanya membaca salah satu bagian dari sebuah bab dalam sebuah kitab, menerjemahkannya ke dalam bahasa Indonesia dan memberikan penjelasan-penjelasan yang diperlukan".30

Berbeda dengan Hasil Musyawarah/ Lokakarya Intensifikasi Pengembangan Pondok Pesantren dalam Abdurrahman Saleh, bahwa metode wetonan ialah "pembacaan satu atau beberapa kitab oleh kiai atau pengasuh dengan memberikan kesempatan kepada para santri untuk menyampaikan pertanyaan atau meminta penjelasan lebih lanjut". ${ }^{31}$

Menurut Armai Arief bahwa: Metode bandongan dalam terapannya yakni kebanyakan atau secara umum Kyai menggunakan bahasa daerah setempat, kyai membaca, menerjemahkan, menerangkan kalimat demi kalimat kitab yang dipelajarinya, santri secara cermat mengikuti penjelasan yang diberikan oleh kyai dengan memberikan catatan-catatan tertentu pada kitabnya masing-masing dengan kode-kode tertentu sehingga kitabnya disebut kitab jenggot karena banyaknya catatan yang menyerupai jenggot seorang kyai. ${ }^{32}$

\footnotetext{
${ }^{28}$ Said Aqil Siradj, Pesantren Masa Depan....Ibid, 280

${ }^{29}$ Ibid., 281.

${ }^{30}$ Endang Turmudi, Perselingkuhan Kiai dan...Ibid, 36.

${ }^{31}$ Abdurrahman Saleh, Pedoman Pembinan Pondok...Ibid, 79.

32 Armai Arief, Pengantar Ilmu dan Metodologi Pendidikan Islam, (Jakarta: Ciputat Press. 2002), 154.
}

Hal ini di lakukan untuk lebih memberikan pemahaman terhadap santri yang diajar lebih dapat dicerna dan mudah di pahami oleh santrinya.

Dari pemaparan di atas dapat dipahami bahwa metode bandongan adalah cara penyampaian guru yang mengajar dengan cara membacakan dan menjelaskan kitab yang isi kitab yang dibaca, sementara santri hanya mendengarkan dan menulis penjelasan yang dijelaskan oleh guru yang mengajar tersebut. Sementara itu metode wetonan agak berbeda sedikit dengan bandongan yaitu dalam metode wetonan santri tidak hanya mendengarkan penjelasan dari guru akan tetapi juga memiliki kesempatan untuk bertanya dan meminta penjelasan lebih lanjut.

2) Metode Sorogan

Metode sorogan adalah "pengajian yang merupakan permintaan dari seorang atau beberapa orang santri kepada kyainya untuk diajari kitab tertentu, pengajian sorogan biasanya hanya diberikan kepada santri-santri yang cukup maju, khususnya yang berminat hendak menjadi kyai". 33 Lebih kanjut Zamakhsyari Dhofier, menjelaskan bahwa: Metode sorogan ialah "seorang murid mendatangi guru yang akan membacakan beberapa baris Al Qur'an atau kitabkitab bahasa Arab dan menerjemahkan kata demi kata ke dalam bahasa tertentu yang pada gilirannya murid mengulangi dan menerjemahkan kata perkata sepersis mungkin seperti yang dilakukan gurunya". ${ }^{34}$

Apabila dicermati penjelasan diatas dapat dipahami bahwa metode sorogan lebih bersifat prifat, dimana santri mendatangi gurunya dan meminta untuk diajarkan kitab tertentu dengan cara seorang guru atau ustadz membacakan isi kitab kemudian menerjemahkan ke dalam bahasa tertentu kemudian diulangi lagi oleh para santri apa yang telah dibacakan dan dijelaskan oleh guru atau ustadz yang mengajar tersebut.

3) Metode Halaqah

Selain itu ada pula metode yang sering di gunakan dalam proses pengajaran kitab kuning yakni metode halaqoh dimana metode ini merupakan kelompok kelas dari sistem weton/bandongan.

Halaqoh dari segi kebahasaan berarti lingkarangan murid atau lingkaran belajar santri. Pelaksanaan metode ini, beberapa orang santri dengan jumlah tertentu membentuk halaqoh yang dipimpin langsung oleh seorang kiai atau ustaz atau juga santri senior untuk membahas atau

\footnotetext{
${ }^{33}$ Nurcholish Madjid, Bilik-bilik pesantren...Ibid, 28.

${ }^{34}$ Zamakhsyari Dhofier, Tradisi Pesantren... Ibid, 28.
} 
mengkaji suatu persoalan yang telah ditentukan sebelumnya.

Dalam pelaksanaannya para santri dengan bebas mengajukan pertanyaan-pertanyaan ataupun pendapatnya. Dengan demikian halaqah memiliki arti diskusi untuk memahami isi kitab bukan untuk mempertanyakan kemungkinan besar salahnya yang diajarkan kitab. Santri yakin bahwa kiai tidak akan mengajarkan hal-hal yang salah dan mereka juga yakin bahwa isi kitab yang dipelajari adalah benar. ${ }^{35}$

\section{Pondok pesantren}

\section{a. Pengertian Pesantren}

Kata pondok berasal dari "funduq (bahasa Arab) yang artinya ruang tidur, asrama atau wisma sederhana, karena pondok memang sebagai tempat penampungan sederhana dari para santri yang jauh dari tempat asalnya. Asrama para santri tersebut berada di lingkungan pesantren yang terdiri dari rumah tinggal kiai, masjid, ruang untuk belajar, mengaji dan kegiatan keagamaan lainnya". 36

Secara etimologis pesantren berasal dari akar kata santri, yaitu istilah yang digunakan bagi orang-orang yang menuntut ilmu agama di lembaga pendidikan Islam tradisional Jawa. Kata "santri" mendapat awalan "pe" dan akhiran "an" yang berarti tempat para santri menuntut ilmu. Kata santri mempunyai arti luas dan sempit.

Dalam arti sempit adalah santri adalah seorang murid satu sekolah agama yang disebut pondok atau pesantren. Oleh sebab itulah perkataan pesantren diambil dari kata santri yang berarti tempat tinggal untuk para santri. Sedangkan dalam arti luas dan umum santri adalah bagian penduduk Jawa yang memeluk Islam secara benar-benar, sembahyang, pergi ke masjid dan melakukan aktifitas lainnya. ${ }^{37}$

Dengan demikian dapat diketahui bahwa pesantren didefinisikan sebagai suatu tempat pendidikan dan pengajaran yang menekankan pelajaran agama Islam dan didukung asrama sebagai tempat tinggal para santri. Maka, pesantren kilat atau pesantren Ramadhan yang diadakan di sekolah-sekolah umum misalnya, tidak termasuk dalam pengertian ini.

b. Unsur-unsur kelembagaan Pondok Pesantren

Dalam satu pondok pesantren terdapat beberapa unsur kelembagaan. Di antaranya adalah:

\footnotetext{
${ }^{35}$ Samsul Nizar, Sejarah Sosial...Ibid, 163.

${ }^{36}$ Zuhairi Misrawi, Hadratussyaikh Hasyim Asy'ari Moderasi, Keumatan, dan Kebangsaan, (Jakarta: Kompas. 2010), 223.

37 Abdul Munir Mulkhan, Runtuhnya Mitos Politik Santri, Strategi Kebudayaan dalam Islam, (Yogyakarta: Sipress, 1994), cet. ke-I,
} 1 .
1) Kiai

Kiai adalah unsur yang sensual dari suatu pesantren. Kiai adalah gelar bagi seseorang yang memiliki pengetahuan agama yang luas, memiliki kesalehan yang baik dan mempunyai kepribadian yang terpuji. Bila dihubungkan dengan konteks pesantren, kiai merupakan pendiri dan pemilik pesantren tersebut, memiliki murid atau santri, serta hidupnya semata-mata untuk agama dan masyarakat. ${ }^{38}$

2) Santri

Penggunaan istilah santri "ditujukan pada orang yang sedang menuntut pengetahuan agama di pondok pesantren", ${ }^{39}$ namun pengertian istilah santri memiliki arti dan persepsi yang berbedabeda. Meskipun secara umum santri identik dengan peserta didik, murid, siswa, atau pelajar yang sedang menuntut ilmu pada suatu lembaga pendidikan.

Dalam versi yang hampir sama, Samsul Nizar menjelaskan bahwa "pondok, masjid, santri, kiai dan pengajaran kitab-kitab klasik merupakan lima elemen dasar yang dapat menjelaskan secara sederhana apa sesungguhnya hakikat pesantren yang membedakannya dengan lembaga pendidikan lain". 40

c. Fungsi Pondok Pesantren

Ada tiga fungsi pesantren yang menjadi karakteristik dari lembaga pondok pesantren salafiyah, yaitu:

1) Transmisi dan transfer ilmu-ilmu Islam;

2) Memelihara tradisi Islam; dan

3) Reproduksi ulama".41

d. Tujuan Pendidikan Pesantren

Tujuan utama pendidikan pondok pesantren adalah menyiapkan calon lulusan yang hanya menguasai masalah agama semata. Rencana pelajaran (kurikulum) ditetapkan oleh kiai dengan menunjukkan kitab-kitab apa yang harus dipelajari. Pengunaan kitab dimulai dari jenis kitab yang rendah dalam satu disiplin ilmu keIslaman sampai pada tingkat yang tinggi. Kenaikan kelas atau tingkat ditandai dengan bergantinya kitab yang telah ditelaah setelah kitab-kitab sebelumnya selesai dipelajarinya.

e. Model-Model Pesantren

1) Pondok Pesantren Salafi

${ }^{38}$ Karel A Steenbrink, Pesantren, Madrasah, Sekolah: Pendidikan Islam Dalam Kurun Modern. (Jakarta, LP3ES, 1986). 109110.

${ }^{39}$ Abdurrahman Wahid, Pesantren Masa Depan, (Bandung: Pustaka Hidayah, 1999), 14

${ }^{40}$ Syamsul Nizar. Sejarah Sosial ...Ibid, 92

${ }^{41}$ Azyumardi Azra, Pesantren Kontinuitas dan Perubahan, dalam Nurcholis Majid, Bilik-bilik Pesantren, (Jakarta Paramadina, 1997), xxi 
Kata salaf berasal dari bahasa Arab Salaf. Artinya "yang dahulu atau klasik". ${ }^{42}$ Pesantren yang tetap mempertahankan pelajaran kitab-kitab klasik dan tanpa diberikan pengetahuan umum. Model pengajarannya pun sebagaimana lazim diterapkan dalam pesantren salaf yaitu "dengan metode Sorogan, Weton, dan Bandongan”. ${ }^{43}$

2) Pondok Pesantren Khalaf

Banyak di kenal dalam masyarakat islam atau umum istilah pesantren khalaf. Pondok Pesantren Khalaf artinya "kemudian" atau "belakang", sedangkan ashri artinya "sekarang" atau "modern". Pondok pesantren khalafiyah adalah pondok pesantren yang menyelenggarakan kegiatan pendidikan dengan pendekatan modern, melalui satuan pendidikan formal, baik madrasah (MI, MTs, MA atau MAK), maupun sekolah (SD, SMP, SMU dan SMK), atau nama lainnya tetapi dengan pendekatan klasikal.

\section{PELAKSANAAN KEGIATAN}

Pada bagian ini peneliti akan memaparkan analisis secara lugas dan cermat terkait dengan hasil wawancara, observasi dan dokumentasi agar memperoleh gambaran dan jawaban secara lebih detail terkait dengan jenis-jenis metode yang diterapkan dalam pembelajaran kitab kuning di Pondok Pesantren Khusus Al-Halimy Sesela, cara penerapan masing-masing metode pembelajaran kitab kuning di Pondok Pesantren Khusus AlHalimy Sesela dan tingkat keberhasilannya, dan tingkat kesulitan yang dihadapi guru dalam penerapan metode pembelajaran kitab kuning di Pondok Pesantren Khusus Al-Halimy Sesela dan solusinya.

\section{Jenis-jenis metode yang digunakan dalam pembelajaran kitab kuning di Pondok Khusus Al-Halimy Sesela}

Adapun jenis-jenis metode pembelajaran kitab kuning yang digunakan di Pondok Pesantren Khusus Al-Halimy Sesela adalah:

\section{Metode Bandongan atau Wetonan}

Metode bandongan atau wetonan merupakan salah satu metode pembelajaran yang klasik dan identik dengan pondok pesantren khususnya dalam pelajaran kitab kuning. Di Pondok Khusus Al-Halimy Sesela juga masih menggunakan metode tersebut dan merupakan salah satu metode yang digunakan dalam

\footnotetext{
42 Irfan Hielmy, Pesan Moral dari Pesantren: Menigkatkan Kualitas Umat, Menjaga Ukhuwah, (Bandung: Nuansa, 1999), 32.

${ }^{43}$ Masjkur Anhari, Integrasi Sekolah Ke dalam Sistem Pendidikan Pesantren (Surabaya: Diantama, 2007), 26-27.
}

pembelajaran kitab kuning di Pondok Khusus AlHalimy Sesela.

Metode bandongan atau watonan ini digunakan atau diterapkan di Pondok Khusus AlHalimy Sesela pada waktu mempelajari kitab tafsir (tafsir jalâlain), di mana ustadz membacakan isi kitab kuning yang berbahasa Arab dan tidak berharokat atau berbaris lalu menterjemahkan dan menjelaskan maksud dari teks yang dibaca tersebut. Sementara itu santri hanya duduk mendengarkan dan memperhatikan apa yang dijelaskan oleh ustadz yang mengajar sambil mencatat harokat dari teks kitab kuning yang dibacakan dan menterjemahkan teks tersebut serta mencatat penjelasan-penjelasan yang dijelaskan oleh ustadz.

Para santri mencatat terjemahan teks dan penjelasan-penjelasan yang dijelaskan oleh ustadz langsung di dalam kitab tersebut dan mencatat penjelasan-penjelasanya di samping teks kitab dengan cara memberikan kode-kode khusus untuk mengetahui maksud dari teks tersebut.

Metode ini juga dipilih atau diterapkan karena praktis. Jadi guru atau ustadz yang mengajar langsung membacakan isi atau teks kitab yang tidak berharokat dan berbahasa Arab tersebut lalu kemudian sambil menterjemahkan dan menjelaskan maksud dari teks tersebut, dan santri hanya mendengarkan dan memperhatikan serta mencatat penjelasan dari guru atau ustadz yang mengajar. Jadi guru tidak perlu repot-repot untuk mengatur santri atau mengelompokkan mereka menjadi beberapa kelompok dan memberikan materi dan menggunakan metode yang berbeda.

Namun di samping itu ada juga kelemahankelemahan dari metode bandongan atau wetonan ini yaitu:

a. Kekurangan.

1) Metode ini dianggap lamban dan tradisional, karena dalam menyampaikan materi sering diulang-ulang.

2) Guru lebih kreatif dari pada siswa karena proses belajarnya berlangsung satu jalur (monolog).

3) Dialog antara guru dan murid tidak banyak terjadi sehingga murid cepat bosan.

4) Metode bandongan ini kurang efektif bagi murid yang pintar karena materi yang disampaikan sering diulang-ulang sehingga terhalang kemajuannya. ${ }^{4}$

Karena metode bandongan atau wetonan ini hanya terpusat pada guru saja dengan kurangnya interaksi antara guru dengan murid maka ini

44 http://id.shvoong.com/social-sciences/education/2201153sistem-pengajaran-di-pesantren/ \#ixzz1wUcjt4NO, 
menyebabkan murid menjadi bosan sehingga banyak murid atau siswa yang melamun, tidak memperhatikan, asik berbicara dengan temannya yang lain dan ada juga yang bermain-main dibelakang bahkan ada juga yang tertidur saking asiknya mendengarkan guru atau ustadz yang hanya ngomong sendiri tanpa ada timbal balik atau respon dari santri.

\section{Metode Sorogan}

Metode sorogan adalah salah satu metode yang digunakan pada pengajian-pengajian atau pembelajaran-pembelajaran yang sifatnya privat, yang merupakan permintaan dari santri atau dari ustadz. Sebagaimana yang dijelaskan oleh Nurcholis Majid bahwa metode sorogan merupakan "pengajian yang merupakan permintaan dari seorang atau beberapa orang santri kepada kyainya untuk diajari kitab tertentu, pengajian sorogan biasanya hanya diberikan kepada santri-santri yang cukup maju, khususnya yang berminat hendak menjadi kyai". 45

Metode sorogan ini juga diterapkan di Pondok Khusus Al-Halimy Sesela dalam pembelajaran kitab kuning untuk memberikan pelajaran tambahan bagi santri yang ingin memperdalam pengetahuan tentang kitab kuning atau bagi santri yang belum atau kurang dalam memahami kitab kuning.

Metode ini dipilih atau diterapkan di Pondok Khusus Al-Halimy Sesela agar memudahkan santri dalam berinteraksi dengan gurunya karena metode ini sifatnya privat maka santri akan leluasa bertanya tentang apa saja yang belum dipahami dari pelajaran tersebut, karena kalau di kelas mereka malu untuk bertanya atau mengeluarkan pendapatnya karena malu terhadap temantemannya kalau-kalau jawaban atau pertanyaannya salah. Akan tetapi dengan cara penerapan metode sorogan ini santri bebas bertanya dan mengeluarkan pendapatnya tanpa ada rasa malu karena akan dibimbing langsung oleh ustadznya sehingga mereka lebih percaya diri dalam mengikuti pembelajaran. Selain itu santri juga akan lebih merasa diperhatikan dan terkontrol.

\section{Metode Halaqoh}

Halaqoh adalah salah satu metode klasik yang digunakan di pondok pesantren dalam pembelajaran kutab kuning. Metode halaqoh ini juga diterapkan di Pondok Khusus Al-Halimy Sesela. Karena di Pondok Khusus Al-Halimy Sesela tidak menggunakan bangku dan meja ketika belajar maka santri dalam kesehariannya menggunakan sistem halaqoh dalam pembelajaran kitab kuning dengan cara santri duduk bersila dan melingkari ustadz yang mengajar.

Dalam pelaksanaannya santri begkumpul dan membuat lingkaran mengelilingi guru atau ustadz yang mengajar sehingga ustadz berada di tengah-tengah lingkaran, dan siswa atau santri mendengarkan penjelasan dari ustadz dan juga terjadi interaksi antara guru dengan murid, seperti santri bertanya tentang makna atau kalimat yang belum dipahami kemudian ustadz menjawab atau merespon pertanyaan yang diajukan, dan terkadang guru berdiskusi dengan santri tentang materi yang sedang dipelajari.

\section{Metode Diskusi}

Diskusi adalah salah satu jenis metode pembelajaran yang diterapkan di Pondok Khusus Al-Halimy Sesela dalam pembelajaran kitab kuning Metode ini diterapkan pada pelajaran ilmu fiqih (fathu al-qorib) dan ilmu nahwu (ibnu aqil) juga ilmu shorf (kaelani).

Metode ini digunakan pada pelajaran fiqih, nahwu, dan shorf yang notabenenya memang membutuhkan pemahaman yang mendalam, karena itulah metode diskusi dianggap cocok digunakan dalam pelajaran ini, yakni untuk meningkatkan pemahaman mereka terhadap materi yang sudah dipelajari.

Metode diskusi diterapkan di Pondok Khusus Al-Halimy Sesela untuk meningkatkan pemahaman santri terutama bagi santri senior atau yang sudah berada di jenjang MA mulai dari kelas IV sampai kelas VI. Inilah yang dimaksudkan dengan uji publik yaitu salah satu teknis untuk mengetahui keberhasilan suatu metode pembelajaran yang digunakan.

\section{Metode Tanya Jawab}

Salah satu metode pembelajaran yang diterapkan di Pondok Khusus Al-Halimy Sesela adalah metode tanya jawab.

Syahraini Tambak menjelaskan bahwa "metode tanya jawab dalam proses pembelajaran harus dipahami dan ditempatkan pada posisi yang sesungguhnya. Di mana materi pembelajaran dapat dipahami oleh peserta didik secara maksimal melalui metode tanya jawab ini. Oleh karena itu desain metode tanya jawab harus betul-betul diketahui oleh guru agar tujuan pembelajaran dapat tercapai secara maksimal". ${ }^{46}$

Metode tanya jawab digunakan atau diterapkan pada pelajaran ilmu nahwu dan shorf, 
karena dalam pelajaran nahwu shorf banyak kaidah-kaidah yang harus dihafalkan dan dipahami beserta contoh-contoh dan i'rob-i'robnya. Jadi santri dituntut untuk bisa menguasai materimateri tersebut, karena itulah digunakan metode tanya jawab, dengan cara ustadz yang mengajar akan menunjuk satu-persatu santri dan menanyakan tentang suatu kaidah ilmu nahwu dan shorf beserta contoh dan i'robnya.

\section{Metode Ceramah}

Dalam proses belajar mengajar, tentulah harus menggunakan berbagai metode yang sesuai dengan kondisi yang ada, agar tercipta suatu lingkungan belajar yang efektif dan efisien yang membuat peserta didik menjadi senang mengikuti dan melakukannya. Dari sekian banyak metode pembelajaran, metode ceramah adalah metode yang paling umum digunakan oleh guru mulai dari tingkat Taman Kanak-kanak (TK) atau Raudatul Atfal (RA) sampai dengan perguruan tinggi sekalipun. Metode ceramah juga menjadi salah satu metode yang diterapkan di Pondok Khusus AlHalimy Sesela dalam pembelajaran kitab kuning.

Metode ceramah diterapkan di Pondok Khusus Al-Halimy Sesela dalam pembelajaran kitab kuning biasanya diterapkan pada pembelajaran atau pada ilmu yang sudah baku dan tidak banyak membutuhkan respon dari peserta didik atau santri yang berupa cerita-cerita dan amalanamalan dan merupakan informasi-informasi seperti kitab tarikh dan dhurratunnashiîn.

Dalam kitab tarikh berisikan tentang sejarahsejarah, sedangkan dalam kitab dhurratunnashiîn berisi tentang kisah-kisah yang penuh hikmah, amalan-amalan harian dan kelebihan-kelebihannya juga berisi tentang kemuliaan bulan-bulan tertentu beserta amalan-amalannya, dan ini tidak terlalu membutuhkan respon atau timbal balik dari santri hanya membutuhkan perhatian santri dalam mendengarkan pelajaran yang disampaikan.

\section{KESIMPULAN}

Berdasarkan hasil penelitian pengabdian masyarakat "Bimbingan Pembelajaran Kitab Kuning di Pondok Pesantren Khusus Al-halimy Sesela" dapat disimpulkan bahwa:

1. Jenis metode yang diterapkan dalam pembelajaran kitab kuning di Pondok Pesantren Khusus Al-Halimy Sesela adalah Bandongan atau Wetonan, Sorogan, Halaqoh, Diskusi, Tanya Jawab, dan Ceramah.

2. Cara penerapan metode pembelajaran kitab kuning di Pondok Pesantren Khusus Al-Halimy Sesela adalah, metode Bandongan atau
Wetonan dengan cara ustadz membacakan isi kitab, santri hanya memperhatikan penjelasan yang diberikan. Metode Sorogan dengan cara santri yang membaca dan dengarkan oleh ustadz. Metode Halaqoh dengan cara santri begkumpul mengelilingi ustadznya dan mendengarkan penjelasan dari ustadznya. Metode Diskusi, dengan cara ustadz membikin kelompok-kelompok diskusi dengan tema yang sudah ditentukan. Metode Tanya Jawab, dengan cara ustadz bertanya kepada santri pelajaran yang telah dijelaskan. Metode Ceramah, dengan cara ustadz membacakan isi kitab, sementara itu santri hanya mendengarkan penjelasan yang disampaikan.

Adapun kesulitan-kesulitan yang dihadapi guru dalam penerapan metode pembelajaran kitab kuning di Pondok Khusus Al-Halimy sesela adalah santri merasa jenuh ketika penerapan metode Bandongan atau Wetonan, dan solusinya adalah dengan menggabungkan beberapa metode. Dengan metode Sorogan waktu belajar terlalu padat, solusinya dengan cara mengatur jadwal supaya tidak terlalu padat. Metode Halaqoh santri duduk kurang rapi, solusinya dengan mengatur cara duduk santri. Metode Diskusi, terlalu banyak menghabiskan waktu, solusinya dengan mengatur waktu diskusi. Tanya Jawab, guru mengulang kembali pelajaran yang lalu, solusinya dengan menugaskan santri untuk menyimpulkan. Dan Metode Ceramah, santri merasa jenuh dan bosan, solusinya dengan cara menggabungkan beberapa metode.

\section{DAFTAR RUJUKAN}

Abdul Munir Mulkhan. 1994. Runtuhnya Mitos Politik Santri, Strategi Kebudayaan dalam Islam. Yogyakarta: Sipress. cet. ke-I.

Abdul Rachman Shaleh, 2006. Pendidikan Agama Islam dan Pembangunan Watak Bangsa, Jakarta: Raja Grafindo Persada.

Abdurrahman Saleh, 1982. Pedoman Pembinan Pondok Pesantren. Jakarta: Departemen Agama RI.

Abdurrahman Wahid, 1999 Pesantren Masa Depan. Bandung: Pustaka Hidayah.

Abin Syamsudin Makmun, 2009. Psikologi Kependidikan Perangkat Sistem Pengajaran Modul. Bandung : PT Remaja Rosdakarya Offset.

Abuddin Nata, 2009. Perspektif Islam Tentang Strategi Pembelajaran, (Jakarta: kencana Prenada Media Groum. cet. 1.

Afifuddin\& Beni Ahmad Saebani, 2009. Metodologi Penelitian Kualitatif . Bandung: Pustaka Setia.

Ahlan, Tesis: 2015. Metode pembelajaran dalam memahami isi kitab kuning di Ma'had 'Aly Pondok Pesantren Nurul Hakim Kecamatan Kediri Lombok Barat tahun 2015. 
Ahmad Barizi, 20011. Pendidikan Intregratif: Akar Tradisi \& Intregasi Keilmuan Pendidikan Islam, Malang: UIN Maliki Press.

ArmaiArif, 2002. Pengantar dan Metodologi Pendidikan Islam.Jakarta: Ciputat Pers. cet. Ke-1

Azyumardi Azra, 1999. Pendidikan Islam: Tradisidan Modernisasi Menuju Milenium Baru. Jakarta: Logos Wacana Ilmu.

1997. Pesantren Kontinuitas dan Perubahan. Jakarta : Paramadina.

Bungin, M. Burhan.2007. Penelitian Kualitatif: Komunikasi, Ekonomi, Kebijakan Publik, dan Ilmu Sosial Lainnya. Jakarta: Kencana Prenada Media Group.

Darwyan Syah, 2006. Perencanaan Sistem Pengajaran Pendidikan Agama Islam.Jakarta: Faza Media.

Depag RI, Pondok Pesantren dan Madrasah Diniyah....

Emzir, 2012.Metodologi Penelitian Kualitatif :Analisis Data. (Jakarta: PT Raja Grafindo Persada.

Endang Turmudi, 2004. Perseligkuhan Kyaidan Kekuasaan.Yogyakarta: Lkis.

Hamdan Farchan dan Syarifuddin, 2005. Titik Tengkar Pesantren: Resolusi Konflik Masyarakat Pesantren. Yogyakarta: Pilar Religia.

Hamdani, 2011. Strategi Belajar Mengajar. Bandung. Pustaka Setia.

http : // www.psikologizone.com / macam - kesulitan belajar - siswa / 065111779 diakses pada hari Kamis 26 Juni 2017.

Irfan Hielmy, 1999. Pesan Moral dari Pesantren: Menigkatkan Kualitas Umat, Menjaga Ukhuwah. Bandung: Nuansa.

Karel A Steenbrink, 1986.Pesantren, Madrasah, Sekolah: Pendidikan Islam Dalam Kurun Modern. Jakarta: LP3ES.

Lexy J. Moleong, 2012. Metodologi Penelitian Kualitatif. Bandung: PT Remaja Rosdakarya.

Margono, 2003. Metodologi Penelitian Pendidikan. Jakarta: Rineka Cipta. 2005. Metodologi Penelitian Pendidikan. Jakarta: Rineka Cipta.

Martin Van Bruinessen, 1995. KitabKuning: Pesantren dan Tarekat. Bandung: Mizan. 